\title{
The combination effect of adding rosemary extract and oregano essential oil on ground chicken meat quality
}

\author{
Marwan AL-HIJAZEEN ${ }^{1 *}$ (iD
}

\begin{abstract}
Preservative effect of oregano essential oil (OE) and rosemary extract (RE) on ground chicken meat stored at different refrigeration time had been evaluated. Six treatments were prepared: T1) Control (No additives); T2) Combination ( $\left.\mathrm{CM}_{1}\right)$ of $100 \mathrm{ppm}$ OE and 300 ppm RE; T3) $\mathrm{CM}_{2}: 100$ ppm OE + 350 ppm RE; T4) $\mathrm{CM}_{3}: 150$ ppm OE + 300 ppm RE; T5) $\mathrm{CM}_{4}: 150$ ppm OE + 350 ppm RE; T6) $14 \mathrm{ppm}$ of butylated hydroxyanisole (BHA). Meat patties were individually packaged in oxygen-permeable bags stored at $4{ }^{\circ} \mathrm{C}$, and analyzed for lipid and protein oxidation, and CIE color values at 0,4 , and 7 days. Individual cooked thigh meats were used to evaluate different sensory attributes. All additives showed significant $(\mathrm{P}<0.05)$ antioxidant effect delaying lipid and protein oxidation after day 4 comparing to the control treatment samples. However, the highest significant $(\mathrm{P}<0.05)$ effect among all treatments was by $\mathrm{CM}_{4}$. The $\mathrm{CM}_{4}$ was the highest stabilizing raw meat color, and preventing meat discoloration. In addition, it showed $\left(\mathrm{CM}_{4}\right)$ highest overall acceptability scores values regarding sensory evaluation. Based on current results, both $\mathrm{OE}$ and $\mathrm{RE}$ had a potential antioxidant activity; however, this could be stronger if used together.
\end{abstract}

Keywords: oregano essential oil; rosemary extract; protein oxidation; lipid oxidation; ground meat.

Practical Application: Improving ground meat shelf-life and their quality using combined natural plants extracts.

\section{Introduction}

Recently, in food safety and preservation sector it becomes highly recommended to avoid using synthetic antioxidant (Taghvaei \& Jafari, 2015; Pereira et al., 2017; Fruet et al., 2020). Food scientist were extensively investigated this by testing many natural replacements (Candan \& Bagdatli, 2017; Pereira et al., 2017; Aminzare et al., 2019). Currently, synthetic antioxidants (SA) such as butylatedhydroxyanisole (BHA), butylatedhydroxytolune (BHT), Tertiary butyl hydroquinone (TBHQ), are widely used in food containing oil such as meat products (Monahan \& Troy, 1997; Race, 2009). In addition, several commercial meat preservatives also used in the meat industry such as sodium nitrite/nitrate, and potassium nitrite which consider very essential to maintain their color and flavor (Al-Shuibi \& Al-Abdullah, 2002; Decker et al., 2010). However, using these additives frequently in human food may cause possible carcinogenic and toxicological effect (Altmann et al., 1986; Kahl \& Kappus, 1993; Kumar et al., 2015; Fruet et al., 2020). This approach of using natural sources has been growing up rapidly to be used as new meat preservation technology (Shah et al., 2014; Kumar et al., 2015; Manessis et al., 2020). This also connected with the increase in consumer's demands on both natural and organic food in the last two decades (Jensen et al., 2011; Velasco \& Williams, 2011; Pereira et al., 2017). However, it reported that using one natural preservative alone is not effective as the synthetic (commercial) antioxidant (Brewer, 2011; Kumar et al., 2015). Thus, researchers recommended adding these supplements in the form of combination, which may improve their action (Honikel, 2008; Smet et al., 2008; Brewer, 2011; Oostindjer et al., 2014; Hwang et al., 2014). However, researchers still need to investigate their effective level, how it interact in meat system. Rosemary extract and $(\mathrm{OE})$ is one of the most popular natural additives have been tested in different food recently (Liu et al., 2009; Haile, 2015; Pereira et al., 2017; Al-Hijazeen, 2018). These medical plants extracts were evaluated directly through meat surface as (Velasco \& Williams, 2011; Kumar et al., 2015; Zhai et al., 2018), mixing in ground meat (Ahn et al., 2007; Al-Hijazeen, 2014; Al-Hijazeen et al., 2016a, b; Zahid et al., 2018; Manessis et al., 2020), indirectly in the animal feed (Botsoglou et al., 2003; Ri et al., 2017; Sierżant et al., 2018; Cázares-Gallegos et al., 2019), and it mostly showed positive effect enhancing meat quality and extended their shelf-life.

In Jordan, these extracts are widely available in the local market (at low concentration) which applies for different purposes, such as food flavor, pharmaceutical uses, and human health etc (Oran \& Al-Eisawi, 1998; Ibrahim et al., 2012). However, Origanum syriacum L. and Rosmarinus officinalis Linn. extract (Grown under Jordanian Climate conditions) were characterized with a high level of phenolic compounds (Ibrahim et al., 2012; Hudaib et al., 2015; Al-Hijazeen, 2018; Al-Hijazeen \& Al-Rawashdeh, 2019). Generally, the antioxidant effect of these plants extracts are based on their phenolic compounds (Brewer, 2011; Shah et al., 2014). For instance, antioxidant activity of oregano oil linked with their carvacrol and thymol (78-82\%) and the other polyphenolic constituents (Adam et al., 1998; Yanishlieva et al., 1999; Al-Hijazeen, 2018). In addition, they are main components giving their antimicrobial effect against several food borne diseases (Ultee et al., 2002; Nostro et al., 2004, 2007;

*Corresponding author: marwana@mutah.edu.jo, alhijazeenmarwan@gmail.com 
Ahn et al., 2007). Chouliara et al. (2007) found an improvement on chicken meat freshness, shelf life, and decreasing of their microbes (lactic acid bacteria, TVC, pseudomonas spp., yeast) by direct adding oregano essential oil. Rosemary extract had been analyzed of their phenolic constituent's, and it found that carnosic acid, carnosol, rosmanol, rosmariquinone and rosmaridiphenol, ursolic acid, and caffeic acid (Aruoma et al., 1992; Basaga et al., 1997) are causing their antioxidant and antimicrobial activities. In addition, $\mathrm{RE}$ had been documented to have anti-inflammatory, anti-diabectic and anti-cancer activities (Moreno et al., 2006; Khalil et al., 2012; Moore et al., 2016). Ninety percent of RE antioxidant properties is originated from both carnosic and carnosol constituent's (Aruoma et al., 1992; Erkan et al., 2008). However, the suitable level of RE that should be use in meat system is still under investigation and affected by several factors (Al-Hijazeen \& Al-Rawashdeh, 2019; Duoxia et al., 2020). Furthermore, there were no research study investigate the combination effect of Rosmarinus officinalis Linn. extract and Origanum syriacum L. essential oil (grown in Jordan), and their level, on ground chicken meat. In addition, this combination may have synergistic effect preventing rancidity development and improve meat shelf life. The objectives of current research were: 1) to evaluate the effect of adding different combination of RE and $\mathrm{OE}$ on broiler meat quality;2) compare their effect with the synthetic antioxidant $\mathrm{BHA} ; 3)$ determine the best combination level that could be use in the meat industry.

\section{Materials and methods}

\subsection{Meat preparation}

All meat were deboned, cleaned, and stored as described by Al-Hijazeen \& Al-Rawashdeh (2019). Chicken thigh meat was purchased from a local slaughtering plant and ground (twice) a through a $8-\mathrm{mm}$ plate then a $3-\mathrm{mm}$ plate (Moulinex, Type DKA1, France). Prepared treatments were including: T1) Control (No additives); T2) Combination $\left(\mathrm{CM}_{1}\right)$ of $100 \mathrm{ppm}$ $\mathrm{OE}$ and $300 \mathrm{ppm} \mathrm{RE;} \mathrm{T3)} \mathrm{CM}_{2}: 100 \mathrm{ppm} \mathrm{OE}+350 \mathrm{ppm} \mathrm{RE}$; T4) $\mathrm{CM}_{3}: 150 \mathrm{ppm} \mathrm{OE}+300 \mathrm{ppm} \mathrm{RE}$; T5) $\mathrm{CM}_{4}: 150 \mathrm{ppm}$ $\mathrm{OE}+350 \mathrm{ppm}$ RE; T6) $14 \mathrm{ppm}$ of butylated hydroxyanisole (BHA). Oregano essential oil (OE) and RE concentration were chosen based on several preliminary and original meat quality studies considering their antioxidant activities (Al-Hijazeen \& Al-Rawashdeh, 2019; Al-Hijazeen, 2018). Oregano essential oil (Origanum syriacum L.) was purchased from a certified company (Green Fields Factory for oils, Amman/Jordan) using the most efficient purification, extraction, and steam distillation methods. The HPLC analysis (Royal Scientific Society, Jordan, Amman research institution (RSS)) of the OE showed that $76.39 \%$ of the essential oil was carvacrol. Rosemary extract (Extracted from cultivated rosemary in Jordan) was obtained from the same source, and the HPLC analysis (RSS) of the RE was measured as described by the method of Okamura et al. (1994), and it was containing $26 \pm 3 \%$ as the average of phenolic diterpenes ( $4 \%$ carnosol and $6 \%$ carnosic acid and other phenolic constituents). The BHA powder, RE, and OE were dissolved in $10 \mathrm{~mL}$ of $100 \%$ ethanol, and then mixed with $50 \mathrm{~mL}$ mineral oil (Sant Cruz Biotechnology, Dallas, TX, USA) to prepare their stock solution. The ethanol mixed with mineral oil was split out using a rotary evaporator (Heidolph, Model Laborota 4001-effecient) at $\left(70^{\circ} \mathrm{C}, 175\right.$ mbar vacuum pressure) before adding the stock to the meat mixture. All supplements were added to the ground meat, and then mixed for $4 \mathrm{~min}$ in a bowl mixer individually. However, they were supplemented using same quantity of mineral oil to get the same experimental conditions. The individual prepared meat patties (approximately $100 \mathrm{~g}$ each/4 replicate of each treatment) were packaged in oxygen-permeable bags (polyethylene, Size: $11 \times 25 \mathrm{~cm}$, Future for Plastic Industry, $\mathrm{Al}$-Moumtaz bags, Co. L.T.D, Jordan), stored at $4{ }^{\circ} \mathrm{C}$ cooler for up to 7 days, and analyzed for lipid and protein oxidation, and CIE color values at 0,4 , and 7 days. In the cooked section, the raw meat samples were first packaged in oxygen impermeable vacuum bags (Albalabki-Jordan, Malcom SRL, Milano, Italy), and the meat were cooked in-bag in a $90^{\circ} \mathrm{C}$ water bath (Memmert, WNB 14; $\mathrm{GMbH}+\mathrm{Co} . \mathrm{KH}, \mathrm{D}-91107$ Schwabach, Germany) until the internal temperature of the meat patties reached to $75^{\circ} \mathrm{C}$. After cooling to room temperature, meat samples (cooked) was transferred to a new oxygen-permeable bag (polyethylene, Size: $11 \times 25 \mathrm{~cm}$, Future for Plastic Industry, Al-Moumtaz bags, Co. L.T.D, Amman, Jordan), and stored at $4{ }^{\circ} \mathrm{C}$ for up to 7 days to be analyzed for quality parameters. Same preparation method was done for all sensory analysis treatments samples. However, the ground (raw) meat patties stored at $4{ }^{\circ} \mathrm{C}$ up to 4 days before cooking and for each evaluation session.

\subsection{Color measurement}

In the meat lab (Department of Animal Production); Konica Minolta Meter (CR-400, Konioca Minolta, Osaka, Japan) was used to measure meat color. The colorimeter was calibrated using an illuminant source $\mathrm{C}$ (Average day light) on a standard ceramic tile enveloped with the same plastic bag used for meat samples. The color values were expressed as CIE L* - (lightness), $\mathrm{a}^{*}$ - (redness), and $\mathrm{b}^{*}$ - (yellowness) values (American Meat Science Association, 2012). The un-uniform (defects) color area where excluded from the targeted measurements. An average of two random readings on the top of the sample surface was used for statistical analysis.

\subsection{Thiobarbituric acid-reactive substances (TBARS) measurement}

Lipid oxidation in ground meat sample was determined using a TBARS method (Ahn et al., 1998) with minor modification as described by Al-Hijazeen et al. (2016a). All chemicals, stock solution, and equipment were prepared before starting chemical analysis. The TBARS number was expressed as mg of malondialdehyde (MDA) per kg of meat.

\subsection{Protein oxidation}

Protein oxidation (DNPH: 2.4-Dinitrophenylhydrazine) values was estimated using the general method of total carbonyl value described by Lund et al. (2008) and as reported and modified by Al-Hijazeen (2018). The carbonyl content was calculated as $\mathrm{nmol} / \mathrm{mg}$ protein using absorption coefficient of $22,000 / \mathrm{M} / \mathrm{cm}$ as described by Levine et al. (1994). 


\subsection{Sensory panel evaluation}

Highly trained sensory panels (10 panelists) were used to evaluate certain sensory attributes of the ground chicken (cooked thigh) meat similarly (Same procedure, scale, and preparation method for all attributes used) as described by Al-Hijazeen \& Al-Rawashdeh (2019).

\subsection{Statistical analysis}

Data were analyzed using the procedures of generalized linear model (Proc. GLM, SAS program, version 9.3, 2012). Mean values and standard error of the means (SEM) were reported (SAS Institute, 2012). The significance was defined at $\mathrm{P}<0.05$ and Tukey test or Tukey's Multiple Range test were used to determine the significant differences between the mean values.

\section{Results and discussion}

Generally, both RE and OE have no significant effect on the ultimate $\mathrm{pH}$ of raw meat, and cooking loss \%, as it reported in previous studies (Al-Hijazeen \& Al-Rawashdeh, 2019; Al-Hijazeen, 2019). This enhance the univariate analysis between treatments especially lipid and protein oxidation measurements. Therefore, any treatments variation in this study will be due to treatments additive effect. In addition, current study is a part of meat quality and safety evaluation project (GN: 120/14/118) which designed to evaluate both OE and RE antioxidant/ antimicrobial effect using ground chicken meat.

\subsection{Lipid oxidation}

Among all treatments tested by TBARS method (Ahn et al., 1998) there were no significant differences $(\mathrm{P}>0.05)$ at day 0 for both raw and cooked meat mean values. However, all treatments additives showed significant antioxidant effect $(\mathrm{P}<0.05)$ compared to the control samples after day 4 (Table 1). This was in agreement with previous studies (Liu et al., 2009; Kahraman et al., 2015; Al-Hijazeen et al., 2016a; Al-Hijazeen \& Al-Rawashdeh, 2019; Al-Hijazeen, 2019), tested different level of OE and RE using ground chicken meat. In addition, the effect of adding OE was positively extends chicken meat shelf life, decrease off-odor flavor, and delay rancidity development (Chouliara et al., 2007; Fasseas et al., 2008; Kumar et al., 2015; Manessis et al., 2020).

Cooking increase lipid oxidation (primary and secondary products) by disrupting cell membranes, and releasing more pro-oxidants (Ahn \& Lee, 2002; Sampaio et al., 2012). Thus, the variation among cooked meat treatments is obvious and more significant compared to the raw meat (Ahn et al., 2009; Al-Hijazeen et al., 2016a). Usually, cooking denatured the antioxidant enzymes, releasing the free iron to extracellular fluid, disrupt phospholipid bi-layer in cells membrane which make internal cell more susceptible for oxygen and catalysts (Gray et al., 1996; Ahn \& Lee, 2002). As in current study, there were no significant differences $(\mathrm{P}>0.05)$ appeared between all additives at day 4 and 7 of storage time using raw thigh meat. On the other hand, $\mathrm{CM}_{3}$ and $\mathrm{CM}_{4}$ was showed the highest significant $(\mathrm{P}<0.05)$ effect decreasing malonaldehyde formation in the meat samples. This may be due their high concentration (\%) of both extract compared to other treatments. All combination treatments were showed higher significant $(\mathrm{P}<0.05)$ effect compared to the synthetic antioxidant (BHA) at day 7 using cooked meat samples. However, synthetic BHA effect usually enhanced by adding another secondary (synergistic) antioxidant which should be considers later (Rowe et al., 2009; Sonam \& Guleria, 2017). This agreed with the several research studies which suggested that adding natural antioxidants in combination could be competitive to the effect of using synthetic additives (Honikel, 2008; Smet et al., 2008; Brewer, 2011; Oostindjer et al., 2014; Hwang et al., 2014; Sonam \& Guleria, 2017). However, even the synergistic effect was not achieved, it was concluded that adding both OE and RE in combination (additive effect) will be better than using them separately. This antioxidant activity of these plant extract linked with the high content of poly phenolic compound (Brewer, 2011; Kumar et al., 2015). Both OE and $\mathrm{RE}$ contain many phenolic compounds (carvacrol and thymol; carnosic and carnosol) decrease rancidity development and enhance chicken meat reducing capacity (Al-Hijazeen, 2018; Al-Hijazeen \& Al-Rawashdeh, 2019). The CM treatment showed the lowest TBARS values at day 7 using both raw and cooked meat. Finally, there was a questionable variation between many research studies evaluating $\mathrm{RE}$ and $\mathrm{OE}$ of their recommended level (Sebranek et al., 2005; Kahraman et al., 2015; Alhijazeen et al., 2016a; Al-Hijazeen \& Al-Rawashdeh, 2019; Al-Hijazeen, 2019).

Table 1. ${ }^{*}$ TBARS values of ground thigh meat at different storage time at $4{ }^{\circ} \mathrm{C}$.

\begin{tabular}{|c|c|c|c|c|c|c|c|}
\hline \multirow{2}{*}{ Time } & \multirow{2}{*}{ Control } & $\mathrm{CM}_{1}$ & $\mathrm{CM}_{2}$ & $\mathrm{CM}_{3}$ & $\mathrm{CM}_{4}$ & \multirow{2}{*}{ BHA } & \multirow{2}{*}{ SEM } \\
\hline & & \multicolumn{4}{|c|}{ - TBARS (mg/kg)meat --- } & & \\
\hline \multicolumn{8}{|l|}{ Raw meat } \\
\hline Day 4 & $1.24^{\text {ay }}$ & $0.32^{\text {by }}$ & $0.27^{\text {by }}$ & $0.24^{\text {by }}$ & $0.23^{\text {by }}$ & $0.33^{\text {by }}$ & 0.035 \\
\hline Day 7 & $2.60^{\mathrm{ax}}$ & $0.99^{\mathrm{bx}}$ & $0.75^{\mathrm{bx}}$ & $0.73^{\mathrm{bx}}$ & $0.67^{\mathrm{bx}}$ & $0.96^{\mathrm{bx}}$ & 0.086 \\
\hline SEM & 0.56 & 0.032 & 0.067 & 0.07 & 0.063 & 0.02 & \\
\hline Day 4 & $3.21^{\text {ay }}$ & $1.32^{\text {cy }}$ & $1.27^{\mathrm{cy}}$ & $1.13^{\text {cy }}$ & $1.06^{\mathrm{cy}}$ & $1.77^{\text {by }}$ & 0.070 \\
\hline Day 7 & $7.19^{\mathrm{ax}}$ & $2.20^{\mathrm{cx}}$ & $2.06^{\mathrm{cdx}}$ & $1.70^{\operatorname{dex}}$ & $1.45^{\mathrm{ex}}$ & $2.68^{\mathrm{bx}}$ & 0.092 \\
\hline SEM & 0.118 & 0.04 & 0.099 & 0.088 & 0.067 & 0.088 & \\
\hline
\end{tabular}

*TBARS value in mg malonaldehyde/kg meat. Treatments: Control (No additives); $\mathrm{CM}_{1}: 100 \mathrm{OE}$ and $300 \mathrm{RE} ; \mathrm{CM}_{2}: 100 \mathrm{OE}+350 \mathrm{RE} ; \mathrm{CM}: 150 \mathrm{OE}+300 \mathrm{RE} ; \mathrm{CM}: 150 \mathrm{OE}+350 \mathrm{RE}$; BHA: 14 ppm of butylatedhydroxyanisole; SEM: Standard error of the means. ${ }^{\mathrm{a}-\mathrm{c}}$ Value with different letters within a row are significantly different $(\mathrm{P}<0.05)$. $\mathrm{n}=4 .{ }^{\mathrm{x}-\mathrm{z}}$ Value with different letters within a column are significantly different $(\mathrm{P}<0.05)$ 


\subsection{Protein oxidation}

This study was using chicken thigh meat instead of breast meat since it contain more fat and myoglobin causing more significant variation between treatments (Ahn et al., 2009; Al-Hijazeen, 2019). Among all treatments, there were no significant differences $(\mathrm{P}>0.05)$ between total carbonyl mean values at day 0 for both raw and cooked meat samples (Table 2).

This may be due to the low amount of total carbonyl formed when evaluating raw meat as reported by Al-Hijazeen (2018) and Al-Hijazeen \& Al-Rawashdeh (2019). Similar findings were reported by Xiao et al. (2011) who also found low total carbonyl values ( 0.46 to $0.80 \mathrm{nmol} / \mathrm{mg}$ protein) using raw ground chicken meat. The total carbonyl results is also agreed with several studies conducted on different meat type where the values of raw meat arranged between $1-3 \mathrm{nmol} / \mathrm{mg}$, and $5 \mathrm{nmol} / \mathrm{mg}$ protein of cooked meat, depending on several internal/external factors (Requena et al., 2003; Estévez, 2011; Sun et al., 2010). However, all supplements were showed significant $(\mathrm{P}<0.05)$ effect decreasing carbonyl formation after day 4 using both raw and cooked meat. This was in agreement with previous studies evaluation both $\mathrm{OE}$ and $\mathrm{RE}$ separately (Al-Hijazeen, 2018; Al-Hijazeen \& Al-Rawashdeh, 2019). During the experimental period there were no significant differences $(\mathrm{P}>0.05)$ between both $\mathrm{BHA}$ and $\mathrm{CM}_{1}$ treatments of the total carbonyl means values. The antioxidant activity of $\mathrm{RE}$ and $\mathrm{OE}$ against the formation of carbonyl compounds are well documented (Estévez et al., 2005; Jongberg et al., 2013; Kumar et al., 2015; Al-Hijazeen \& Al-Rawashdeh, 2019). The antioxidant mechanism of these extracts (RE \& OE) are highly depends on their content of phenols. These phenolic compounds surrounding by several $\mathrm{OH}$ group which work as hydrogen donor, and retarding the initial auto-oxidation process (Lee et al., 2003; Estévez et al., 2005; Manessis et al., 2020). In addition, it is also correlated with the TBARS results as it agreed by Al-Hijazeen et al. (2016a, b) done previously, and several related studies (Howell et al., 2001; Lund et al., 2011; Estévez, 2011).

Furthermore, the highest significant $(\mathrm{P}<0.05)$ antioxidant effect were appeared using $\mathrm{CM}_{3}$ and $\mathrm{CM}_{4}$ additives compared to the other treatments using cooked meat samples at day 4 and 7. Overall, total carbonyl values were higher using cooked meat compared to the raw meat samples. This might be due to the loss of the antioxidant capacity and the denaturation of meat protein during cooking (Ahn \& Lee, 2002; Fasseas et al., 2008; Serpen et al., 2012). This also explains why cooked meat showed more variation between treatments compared to the raw meat in current study.

\subsection{Meat color}

Chicken thigh meat were used to evaluate the antioxidant effect, since it contain high myoglobin and lipid percentage which give better significances compared to the breast meat (Al-Hijazeen, 2014). There were no significant differences $(\mathrm{P}>0.05)$ among all treatments means values of all color parameters $\left(\mathrm{a}^{*}, \mathrm{~L}^{*}\right.$, and $\left.\mathrm{b}^{*}\right)$ at day 0 of storage time (Table 3 ). This confirms that there were no treatments direct-effects on myoglobin chemical status or color values after mixing. This finding agreed with Al-Hijazeen et al. (2016a) and Al-Hijazeen \& Al-Rawashdeh (2019) where OE, and RE additives used to evaluate its separate antioxidant effect. The $L^{*}$ and $a^{*}$ values were decreased significantly $(\mathrm{P}<0.05)$ during storage time $(0-7$ days $)$ among all samples of control treatment. This agreed with several research studies conducted on measuring fresh meat color (Chouliara et al., 2007; Al-Hijazeen et al., 2016a; Al-Hijazeen \& Al-Rawashdeh, 2019). The decrease in ${ }^{*}$ values during storage is based on what happen through discoloration process, and the increase in met-myoglobin pigment formation (Mancini \& Hunt, 2005; Keokamnerd et al., 2008). The $L^{*}$ values was significantly $(\mathrm{P}<0.05)$ higher using $\mathrm{CM}_{4}$ compared to the control samples at day 4 and 7 of storage (at $4{ }^{\circ} \mathrm{C}$ ) time. However, there were no significant differences $(\mathrm{P}>0.05)$ appeared between all treatments additives at day 4 of storage time using $\mathrm{L}^{*}$ value. The $\mathrm{CM}_{4}$ showed the highest stabilizing effect on the $L^{*}$ value of the ground chicken meat compared to the other treatments. Similar trend in $\mathrm{a}^{\star}$ values appeared, and there were no significant differences $(\mathrm{P}>0.05)$ between these treatments additives. However the $\mathrm{CM}_{4}$ showed the highest effect maintaining meat color stability, and preventing their discoloration. The ability of RE and OE to maintain meat redness during storage are highly documented and well evaluated (Estévez et al., 2005; Keokamnerd et al., 2008; Kumar et al., 2015; Al-Hijazeen et al., 2016a; Al-Hijazeen \& Al-Rawashdeh, 2019). This anti-discoloration ability is linked

Table 2. Effect of adding different level of $\mathrm{OE}$ and RE on protein oxidation of ground chicken meat during storage time.

\begin{tabular}{|c|c|c|c|c|c|c|c|}
\hline Time & Control & $\mathrm{CM}_{1}$ & $\mathrm{CM}_{2}$ & $\mathrm{CM}_{3}$ & $\mathrm{CM}_{4}$ & BHA & SEM \\
\hline \multicolumn{8}{|l|}{ Raw meat } \\
\hline Day 4 & $1.35^{\text {ay }}$ & $0.87^{\mathrm{bxy}}$ & $0.81^{b x}$ & $0.77^{\mathrm{bx}}$ & $0.73^{\text {bxy }}$ & $0.89^{\text {by }}$ & 0.065 \\
\hline Day 7 & $2.00^{\mathrm{ax}}$ & $1.07^{\mathrm{bcx}}$ & $0.93^{c x}$ & $0.87^{\mathrm{cx}}$ & $0.84^{\mathrm{cx}}$ & $1.30^{\mathrm{bx}}$ & 0.079 \\
\hline SEM & 0.08 & 0.07 & 0.09 & 0.07 & 0.045 & 0.08 & \\
\hline Day 0 & $1.55^{\mathrm{az}}$ & $1.45^{\mathrm{ay}}$ & $1.42^{\mathrm{az}}$ & $1.42^{\mathrm{az}}$ & $1.37^{\mathrm{ay}}$ & $1.48^{\mathrm{az}}$ & 0.05 \\
\hline Day 4 & $3.10^{\text {ay }}$ & $2.63^{\mathrm{bx}}$ & $2.15^{\mathrm{cy}}$ & $1.75^{\mathrm{dy}}$ & $1.51^{\mathrm{dxy}}$ & $2.66^{\text {by }}$ & 0.088 \\
\hline Day 7 & $4.60^{\mathrm{ax}}$ & $3.03^{b x}$ & $2.52^{\mathrm{cx}}$ & $2.06^{\mathrm{dx}}$ & $1.70^{\mathrm{dx}}$ & $3.21^{\mathrm{bx}}$ & 0.086 \\
\hline SEM & 0.082 & 0.12 & 0.07 & 0.076 & 0.053 & 0.029 & \\
\hline
\end{tabular}

${ }^{\mathrm{a}-c}$ Value with different letters within a row are significantly different $(\mathrm{P}<0.05) . \mathrm{n}=4 .{ }^{\mathrm{x}-\mathrm{z}}$ Value with different letters within a column are significantly different $(\mathrm{P}<0.05)$. Treatments: Control (No additives); $\mathrm{CM}_{1}: 100 \mathrm{OE}$ and $300 \mathrm{RE}$; $\mathrm{CM}_{2}: 100 \mathrm{OE}+350 \mathrm{RE} ; \mathrm{CM}_{3}$ : $150 \mathrm{OE}+300 \mathrm{RE} ; \mathrm{CM}_{4}: 150$ OE + $350 \mathrm{RE}$; BHA: 14 ppm of butylatedhydroxyanisole; SEM: Standard error of the means. 
Table 3. ${ }^{\star} \mathrm{CIE}$ Color value of ground chicken thigh meat with different level of $\mathrm{OE}$ and RE during storage at $4{ }^{\circ} \mathrm{C}$.

\begin{tabular}{|c|c|c|c|c|c|c|c|}
\hline Time & Control & $\mathrm{CM}_{1}$ & $\mathrm{CM}_{2}$ & $\mathrm{CM}_{3}$ & $\mathrm{CM}_{4}$ & BHA & SEM \\
\hline \multicolumn{8}{|l|}{$\mathrm{L}^{*}$} \\
\hline Day 0 & $56.44^{\mathrm{ax}}$ & $56.19^{a x}$ & $56.05^{\mathrm{ax}}$ & $56.20^{\mathrm{ax}}$ & $56.21^{\text {ax }}$ & $56.31^{\mathrm{ax}}$ & 0.204 \\
\hline Day 7 & $52.40^{\mathrm{bz}}$ & $53.01^{\mathrm{abz}}$ & $53.08^{\mathrm{abz}}$ & $53.52^{\text {aby }}$ & $54.05^{\mathrm{ay}}$ & $53.16^{\mathrm{abz}}$ & 0.277 \\
\hline SEM & 0.153 & 0.207 & 0.172 & 0.408 & 0.203 & 0.134 & \\
\hline \multicolumn{8}{|l|}{$a^{*}$} \\
\hline Day 7 & $7.34^{\mathrm{bz}}$ & $8.69^{\mathrm{az}}$ & $8.84^{\mathrm{az}}$ & $8.85^{\text {ay }}$ & $8.96^{\text {ay }}$ & $8.47^{\text {ay }}$ & 0.139 \\
\hline SEM & 0.093 & 0.131 & 0.089 & 0.161 & 0.107 & 0.161 & \\
\hline \multicolumn{8}{|l|}{$b^{*}$} \\
\hline Day 0 & $16.88^{\mathrm{ax}}$ & $16.98^{\mathrm{axy}}$ & $16.62^{\text {ay }}$ & $16.98^{\mathrm{ay}}$ & $16.95^{\text {ay }}$ & $16.78^{x y}$ & 0.186 \\
\hline Day 4 & $17.28^{\mathrm{ax}}$ & $16.47^{\text {aby }}$ & $16.33^{\text {by }}$ & $16.60^{\text {aby }}$ & $16.67^{\text {aby }}$ & $16.72^{\text {aby }}$ & 0.205 \\
\hline
\end{tabular}

to their polyphenolic content as it discussed before. However, the antioxidant activity of natural RE or OE may enhance when adding them in combination (Georgantelis et al., 2007; Nieto, 2017; Sonam \& Guleria, 2017).

Generally, natural antioxidant activity will increase with higher content of phenolic compounds (Kumar et al., 2015; Al-Hijazeen, 2014; Botsoglou et al., 2003). This may explain the higher effect of the combination $\left(\mathrm{CM}_{4}\right)$ treatment maintaining meat color compared to the other additives. However, there were no significant differences $(\mathrm{P}>0.05)$ between the $\mathrm{CM}_{4}$ and BHA treatment through $\mathrm{a}^{\star}$ and $\mathrm{L}^{*}$ values at day 7 of storage time. Finally, there were no significant differences $(P>0.05)$ among all treatments at day 0 , and 7 regarding $b^{*}$ values. In addition, $b^{\star}$ values were increased significantly $(\mathrm{P}<0.05)$ using all treatments (CM and BHA) levels during storage time.

\subsection{Sensory evaluation}

Among all treatments, $\mathrm{BHA}$ and $\mathrm{CM}_{4}$ showed the highest cooked color attribute scores compared to the other treatments (Table 4). This was due to the ability of these extracts decreasing lipid and protein oxidation which affect overall meat quality and their protein functionality (Estévez et al., 2005; Al-Hijazeen, 2014; Al-Hijazeen \& Al-Rawashdeh, 2019).

The spice odor was more intense in all samples of $\mathrm{CM}_{1}$, $\mathrm{CM}_{2}, \mathrm{CM}_{3}$, and $\mathrm{CM}_{4}$ and significantly $(\mathrm{P}<0.05)$ differ from the other treatments (BHA and Control). The panelists easily distinguish the odor of these plant extracts due to their volatile compounds. However, the highest spice odor was detected in $\mathrm{CM}_{4}$ treatment samples compared to the other additives $\left(\mathrm{CM}_{1-3}\right)$. This connected with the effect of extracts concentration of both $\mathrm{OE}$ and RE among all treatments. Based on the sensory panel of the oxidation odor attribute, all treatments additives were showed lower significant $(\mathrm{P}<0.05)$ values compared to the control. In addition, $\mathrm{CM}_{4}$ showed the highest effect decreasing the rancidity development and their off odor. This was in agreement with previous research studies which used different plants essential oils as meat preservation (Al-Hijazeen, 2014; Al-Hijazeen \& Al-Rawashdeh, 2019; Al-Hijazeen, 2019). The antioxidant activity of OE and RE enhances meat shelf life by retarding the aldehydes, sulfuric, and hydrocarbons compounds which are responsible on the chicken meat rancidity and their off-odor volatiles (Ahn et al., 2009). Furthermore, phenolic compounds of both $\mathrm{OE}$ and $\mathrm{RE}$ delay or prevent the formation of new free radicals during the initiation step of auto-oxidation process (Moreno et al., 2006; Keokamnerd et al., 2008; Kumar et al., 2015). These finding is agreed and linked with the previous chemical analysis (TBARS and DNPH) results during refrigerated storage time. Over all, the $\mathrm{CM}_{3}$ and $\mathrm{CM}_{4}$ treatments showed the highest acceptability attribute scores compared to the other treatments. The positive effect of adding RE and OE on different sensory attributes had been reported in previous research studies done on different meat preparation (Thongtan et al., 2005; Al-Hijazeen, 2014; Feng et al., 2016; Al-Hijazeen \& Al-Rawashdeh, 2019). Finally, $\mathrm{CM}_{4}$ could be a good replacement to the synthetic BHA, and it may have superior characteristics such as flavor, anti-deterioration effect, and more consumer acceptability.

\section{Conclusions}

Adding $\mathrm{OE}$ and RE were showed significant $(\mathrm{P}<0.05)$ antioxidant effect when testing meat TBARS, DNPH, and color's values. Adding these extracts improves both ground meat shelf life, freshness, and their quality. However, the inclusion of $\mathrm{CM}_{4}$ (150 ppm OE and 350 ppm RE) showed the highest antioxidant effect compared to the other treatments. Similar trend found by the $\mathrm{CM}_{4}$ among all sensory attributes used. Generally, The $\mathrm{CM}_{4}$ was the best compared to the other treatments regarding all parameters used. Overall, the combination of RE and $\mathrm{OE}$ could form a good promising in the future of meat industry. In addition, it could be a good natural replacement or partial substitution to the synthetic one. However, their interaction with different food system must consider for recommendation purposes. 
Table 4. Sensory attributes means values of cooked ground thigh chicken meat.

\begin{tabular}{|c|c|c|c|c|}
\hline \multicolumn{5}{|c|}{ Sensory attributes ${ }^{\mathrm{b}}$} \\
\hline \multirow{2}{*}{$\mathrm{TRT}^{*}$} & Cooked & Spice & Oxidation & Over All \\
\hline & Color & Odor & Odor & Acceptability \\
\hline Control & $4.58^{c}$ & $0.67^{c}$ & $6.72^{\mathrm{a}}$ & $4.18^{c}$ \\
\hline $\mathrm{CM}_{1}$ & $5.74^{\mathrm{bc}}$ & $4.72^{\mathrm{b}}$ & $4.82^{\mathrm{b}}$ & $6.68^{\mathrm{ab}}$ \\
\hline $\mathrm{CM}_{2}$ & $6.94^{\mathrm{ab}}$ & $5.60^{\mathrm{b}}$ & $4.76^{\mathrm{b}}$ & $5.99^{\mathrm{b}}$ \\
\hline $\mathrm{CM}_{3}$ & $6.50^{\mathrm{abc}}$ & $5.78^{\mathrm{b}}$ & $3.96^{\mathrm{b}}$ & $6.28^{\mathrm{b}}$ \\
\hline $\mathrm{CM}_{4}$ & $6.82^{\mathrm{ab}}$ & $7.21^{\mathrm{a}}$ & $3.76^{\mathrm{b}}$ & $8.02^{\mathrm{a}}$ \\
\hline BHA & $7.77^{\mathrm{a}}$ & $0.52^{\mathrm{c}}$ & $4.22^{\mathrm{b}}$ & $6.06^{\mathrm{b}}$ \\
\hline SEM $^{c}$ & 0.486 & 0.283 & 0.405 & 0.386 \\
\hline
\end{tabular}

${ }^{*}$ Treatments: Control: No additives; $\mathrm{CM}_{1}: 100 \mathrm{OE}$ and $300 \mathrm{RE} ; \mathrm{CM}_{2}: 100 \mathrm{OE}+350 \mathrm{RE} ; \mathrm{CM}_{3}: 150 \mathrm{OE}+300 \mathrm{RE} ; \mathrm{CM}_{4}: 150 \mathrm{OE}+350 \mathrm{RE} ;$ BHA: 14 ppm of butylatedhydroxyanisole; ${ }^{\mathrm{b} S e n s o r y}$ attributes: Samples were evaluated on day 3; ' SEM: Standard error of the means. ${ }^{a-c}$ Mean within same column with different superscripts are different $(\mathrm{P}<0.05) ; \mathrm{n}=10$.

\section{Acknowledgements}

The Author would like to thank all of the financially support by the Deanship of Scientific Research at Mutah University, Al-karak, Jordan. Grant number: 120/14/118. This funding is highly appreciated with my deep thankful to all other Animal Science Department stuff on their technical assistance and expert advices.

\section{References}

Adam, K., Sivropoulou, A., Kokkini, S., Lanaras, T., \& Arsenakis, M. (1998). Antifungal activities of Origanum vulgare subsp. hirtum, Mentha spicata, Lavandula angustifolia, and Salvia fruticosa essential oils against human pathogenic fungi. Journal of Agricultural and Food Chemistry, 46(5), 1739-1745. http://dx.doi.org/10.1021/jf9708296.

Ahn, D. U., \& Lee, E. J. (2002). Production of off-odor vo.latiles from liposome-containing amino acid homopolymers by irradiation. Journal of Food Science, 67(7), 2659-2665. http://dx.doi. org/10.1111/j.1365-2621.2002.tb08795.x.

Ahn, D. U., Nam, K. C., \& Lee, E. J. (2009). Lipid oxidation and flavor. In M. Du \& R. J. McCormick (Eds.), Applied muscle biology and meat science (Chap. 12, pp. 227-246). Boca Raton: CRS Press. http://dx.doi.org/10.1201/b15797-13.

Ahn, D. U., Olson, D. G., Jo, C., Chen, X., Wu, C., \& Lee, J. I. (1998). Effect of muscle type, packaging, and irradiation on lipid oxidation, volatile production and color in raw pork patties. Meat Science, 49(1), 27-39. http://dx.doi.org/10.1016/S0309-1740(97)00101-0. PMid:22063182.

Ahn, J., Grün, I. U., \& Mustapha, A. (2007). Effect of plant extracts on microbial growth, color change, and lipid oxidation in cooked beef. Food Microbiology, 24(1), 7-14. http://dx.doi.org/10.1016/j. fm.2006.04.006. PMid:16943089.

Al-Hijazeen, M. (2014). Effect of oregano essential oil and tannic acid on storage stability and quality of ground chicken meat (Doctoral dissertation). Iowa State University, Ames. Retrieved from http:// lib.dr.iastate.edu/etd/13966

Al-Hijazeen, M. (2018). Effect of direct adding oregano essential oil (Origanum syriacum L.) on quality and stability of chicken meat patties. Food Science and Technology, 38(1, Suppl. 1), 123-130. http://dx.doi.org/10.1590/1678-457x.17117.

Al-Hijazeen, M. (2019). Preservative effect of Origanum syriacum L. essential oil on stability and quality of cooked chicken meat. Brazilian. Journal of Poultry Science, 21(1), eRBCA-2019-0719. http://dx.doi.org/10.1590/1806-9061-2017-0719.
Al-Hijazeen, M., \& Al-Rawashdeh, M. (2019). Preservative effects of rosemary extract (Rosmarinus officinalis L.) on quality and storage stability of chicken meat patties. Food Science and Technology, 39(1), 27-34. http://dx.doi.org/10.1590/1678-457x.24817.

Al-Hijazeen, M., Lee, E. J., Mendonca, A., \& Ahn, D. U. (2016a). Effect of Oregano essential oil (Origanum vulgare subsp.hirtum) on the storage stability and quality parameters of ground chicken breast meat. Antioxidant, 5(2), 18. http://dx.doi.org/10.3390/antiox5020018. PMid:27338486.

Al-Hijazeen, M., Lee, E. J., Mendonca, A., \& Ahn, D. U. (2016b). Effects of tannic acid on lipid and protein oxidation, color, and volatiles of raw and cooked chicken breast meat during storage. Antioxidant, 5(2), 19. http://dx.doi.org/10.3390/antiox5020019. PMid:27304971.

Al-Shuibi, A. M., \& Al-Abdullah, B. M. (2002). Substitution of nitrite by sorbate and the effect on properties of mortadella. Meat Science, 62(4), 473-478. http://dx.doi.org/10.1016/S0309-1740(02)00041-4. PMid:22061755.

Altmann, H. J., Grunow, W., Mohr, U., Richter-Reichhelm, H. B., \& Wester, P. W. (1986). Effects of BHA and related phenols on the forestomach of rats. Food and Chemical Toxicology, 24(10-11), 1183-1188. http:// dx.doi.org/10.1016/0278-6915(86)90306-6. PMid:3804120.

American Meat Science Association - AMSA. (2012). Meat color measurement guidelines (pp. 1-117). Champaign: AMSA. Retrieved from http://www.meatscience.org

Aminzare, M., Hashemi, M., Ansarian, E., Bimkar, M., Azar, H. H., Mehrasbi, M. R., Daneshamooz, S., Raeisi, M., Jannat, B., \& Afshari, A. (2019). Using natural antioxidants in meat and meat products as preservatives: a review. Advances in Animal and Veterinary Sciences, 7(5), 417-426. http://dx.doi.org/10.17582/journal.aavs/2019/7.5.417.426.

Aruoma, O. I., Halliwell, B., Aeschbach, R., \& Löligers, J. (1992). Antioxidant and pro-oxidant properties of active rosemary constituents: carnosol and carnosic acid. Xenobiotica, 22(2), 257-268. http://dx.doi. org/10.3109/00498259209046624. PMid:1378672.

Basaga, H., Tekkaya, C., \& Acikel, F. (1997). Antioxidative and free radical scavenging properties of rosemary extract. LebensmittelWissenschaft + Technologie, 30(1), 105-108. http://dx.doi.org/10.1006/ fstl.1996.0127.

Botsoglou, N. A., Govaris, A., Botsoglou, E. N., Grigoropoulou, S. H., \& Papageorgiou, G. (2003). Antioxidant activity of dietary oregano essential oil and alpha-tocopheryl acetate supplementation in longterm frozenstored turkey meat. Journal of Agricultural and Food Chemistry, 51(10), 2930-2936. http://dx.doi.org/10.1021/jf021034o. PMid:12720373.

Brewer, M. S. (2011). Natural Antioxidants: sources, compounds, mechanisms of action, and potential applications. Comprehensive 
Reviews in Food Science and Food Safety, 10(4), 221-247. http:// dx.doi.org/10.1111/j.1541-4337.2011.00156.x.

Candan, T., \& Bagdatli, A. (2017). Use of natural antioxidants in poultry meat. Celal Bayar University Journal of Science, 13(2), 279-291.

Cázares-Gallegos, R., Silva-Vázquez, R., Hernández-Martinez, C. A., Gutiérrez-Sot, J. G., Kawas-Garza, J. R., Hume, M. E., \& MéndezZamora, G. M. (2019). Performance, carcass variables, and meat quality of broilers supplemented with dietary Mexican oregano oil. Brazilian Journal of Poultry Science, 21(1), 1-10. http://dx.doi. org/10.1590/1806-9061-2018-0801.

Chouliara, E., Karatapanis, A., Savvaidis, I. N., \& Kontominas, M. G. (2007). Combined effect of oregano essential oil and modified atmosphere packaging on shelf-life extension of fresh chicken breast meat, stored at $4^{\circ} \mathrm{C}$. Food Microbiology, 24(6), 607-617. http://dx.doi. org/10.1016/j.fm.2006.12.005. PMid:17418312.

Decker, E. A., Elias, R. J., \& McCkements, D. J. (2010). Oxidative in foods and beverages and antioxidant applications: management in different industry sectors (Vol. 2, Oxidation and protection of poultry and eggs. 2.6.5. Addition of nitrites and nitrates). Cambridge: Woodhead Publishing.

Duoxia, X., Zhanqun, H., Guorong, L., Yanping, C., Atikorn, P., Hang, X., \& Will, D. (2020). Influence of rosemary extract addition in different phases on the oxidation of lutein and WPI in WPI-Stabilized lutein emulsions. Journal of Food Quality, 2020, 5894646. http://dx.doi. org/10.1155/2020/5894646.

Erkan, N., Ayranci, G., \& Ayranci, E. (2008). Antioxidant activities of rosemary (Rosmarinus Officinalis L.) extract, blackseed (Nigella sativia L.) essential oil, carnosic acid, rosmarinic acid and sesamol. Food Chemistry, 110(1), 76-82. http://dx.doi.org/10.1016/j. foodchem.2008.01.058. PMid:26050168.

Estévez, M. (2011). Protein carbonyls in meat system: a review. Meat Science, 89(3), 259-279. http://dx.doi.org/10.1016/j.meatsci.2011.04.025. PMid:21621336.

Estévez, M., Ventanas, S., \& Cava, R. (2005). Protein oxidation in frankfurters with increasing levels of added rosemary essential oil: effect on color and texture deterioration. Journal of Food Science, 70(7), c427-c432. http://dx.doi.org/10.1111/j.1365-2621.2005.tb11464.x.

Fasseas, M. K., Mountzouris, K. C., Tarantilis, P. A., Polissiou, M., \& Zervas, G. (2008). Antioxidant activity in meat treated with oregano and sage essential oils. Food Chemistry, 106(3), 1188-1194. http:// dx.doi.org/10.1016/j.foodchem.2007.07.060.

Feng, L., Shi, C., Bei, Z., Li, Y., Yuan, D., Gong, Y., \& Han, J. (2016). Rosemary extract in combination with Polylysine enhance the quality of chicken breast muscle during refrigerated storage. International Journal of Food Properties, 19(10), 2338-2348. http://dx.doi.org/10 $.1080 / 10942912.2015 .1130053$.

Fruet, A. P. B., Giotto, F. M., Fonseca, M. A., Nörnberg, J. L., \& De Mello, A. S. (2020). Effects of the incorporation of tannin extract from quebracho, and sensory attributes of beef patties. Foods, 9(5), 667. http://dx.doi.org/10.3390/foods9050667. PMid:32455684.

Georgantelis, D., Ambrosiadis, I., Katikou, P., Blekas, G., \& Georgakis, S. A. (2007). Effect of rosemary extract, chitosan and a-tocopherol on microbiological parameters and lipid oxidation of fresh pork sausage stored at $4{ }^{\circ} \mathrm{C}$. Meat Science, $76(1), 172-181$. http://dx.doi. org/10.1016/j.meatsci.2006.10.026. PMid:22064204.

Gray, J. I., Gomaa, E. A., \& Buckley, D. J. (1996). Oxidative quality and shelf life of meats. Meat Science, 43, 111-123. http://dx.doi. org/10.1016/0309-1740(96)00059-9. PMid:22060645.

Haile, D. M. (2015). A comparative study on the effect of rosemary extract and sodium ascorbate on lipid and pigment oxidative stability of liver pate. Journal of Food Science and Technology, 52(2), 992-999. http://dx.doi.org/10.1007/s13197-013-1087-7. PMid:25694710.

Honikel, K.-O. (2008). The use and control of nitrate and nitrite for the processing of meat products. Meat Science, 78(1-2), 68-76. http:// dx.doi.org/10.1016/j.meatsci.2007.05.030. PMid:22062097.

Howell, N. K., Herman, H., \& Li-Chan, E. C. Y. (2001). Elucidation of protein-lipid interactions in lysozyme - Corn oil system by Fourier transform Raman spectroscopy. Journal of Agricultural and Food Chemistry, 49(3), 1529-1533. http://dx.doi.org/10.1021/jf001115p. PMid:11312891.

Hudaib, M. M., Tawaha, K., Hudaib, H. S., \& Battah, A. H. (2015). Chemical composition of volatile oil from the aerial parts of Rosmarinus officinalis L. grown in Jordan. Journal of Essential Oil Bearing Plants, 18(5), 1282-1286. http://dx.doi.org/10.1080/09720 60X.2014.895188.

Hwang, K.-E., Kim, H.-W., Song, D.-H., Kim, Y.-J., Ham, Y.-K., Choi, Y.-S., Lee, M.-A., \& Kim, C.-J. (2014). Enhanced Antioxidant Activity of Mugwort herb and vitamin C in combination on shelf-life of chicken nuggets. Han-gug Chugsan Sigpum Hag-hoeji, 34(5), 582590. http://dx.doi.org/10.5851/kosfa.2014.34.5.582. PMid:26761491.

Ibrahim, R. W., Haddad, N., Haddadin, M., \& Abu-Salah, K. (2012). Evaluation of agro-morphological characters and oil percentage of Origanum syriacum L. and Origanum majorana L. at three dates of initial cutting. Jordan Journal of Agricultural Sciences, 8(1), 33-44.

Jensen, K. O., Denver, S., \& Zanoli, R. (2011). Actual and potential development of consumer demand on the organic food market in Europe. NJAS Wageningen Journal of Life Sciences, 58(3-4), 79-84. http://dx.doi.org/10.1016/j.njas.2011.01.005.

Jongberg, S., Torngren, M. A., Gunvig, A., Skibsted, L. H., \& Lund, M. N. (2013). Effect of green tea or rosemary extract on protein oxidation in Bologna type sausages prepared from oxidatively stressed pork. Meat Science, 93(3), 538-546. http://dx.doi.org/10.1016/j. meatsci.2012.11.005. PMid:23273462.

Kahl, R., \& Kappus, H. (1993). Toxicology of the synthetic antioxidants BHA and BHT in comparison with the natural antioxidant vitamin E. Zeitschrift fur Lebensmittel-Untersuchung und-Forschung, 196(4), 329-338. http://dx.doi.org/10.1007/BF01197931. PMid:8493816.

Kahraman, T., Issa, G., Bingol, E. B., Kahraman, B. B., \& Dumen, E. (2015). Effect of rosemary essential oil and modified-atmosphere packaging (MAP) on meat quality and survival of pathogens in poultry fillets. Brazilian Journal of Microbiology, 46(2), 591-599. http://dx.doi.org/10.1590/S1517-838246220131201. PMid:26273279.

Keokamnerd, T., Acton, J. C., Han, I. Y., \& Dawson, P. L. (2008). Effect of commercial rosemary oleoresin preparations on ground chicken thigh meat quality packaged in a high-oxygen atmosphere. Poultry Science, 87(1), 170-179. http://dx.doi.org/10.3382/ps.2007-00066. PMid:18079467.

Khalil, O. A., Ramadan, K. S., Danial, E. N., Alnahdi, H. S., \& Ayaz, N. O. (2012). Antidiabetic activity of Rosemarinus officinalis and its relationship with the antioxidant property. African Journal of Pharmacy and Pharmacology, 6(14), 1031-1036.

Kumar, Y., Yadav, D. N., Ahmad, T., \& Narsaiah, K. (2015). Recent trend in the use of natural antioxidants for meat and meat products. Comprehensive Reviews in Food Science and Food Safety, 14(6), 796812. http://dx.doi.org/10.1111/1541-4337.12156.

Lee, K. W., Everts, H., Kappert, H. J., Frehner, M., Losa, R., \& Beynen, A. (2003). Effects of dietary essential oil components on growth performance, digestive enzymes and lipid metabolism in female broiler chickens. British Poultry Science, 44(3), 450-457. http://dx.doi. org/10.1080/0007166031000085508. PMid:12964629. 
Levine, R. L., Williams, J. A., Stadtman, E. R., \& Shacter, E. (1994). Carbonyl assays for determination of oxidatively modified proteins. Methods in Enzymology, 233, 346-357. http://dx.doi.org/10.1016/ S0076-6879(94)33040-9. PMid:8015469.

Liu, D. C., Tsau, R. T., Lin, Y. C., Jan, S. S., \& Tan, F. J. (2009). Effect of various levels of rosemary or Chinese mahogany on the quality of fresh chicken sausage during refrigerated storage. Food Chemistry, 117(1), 106-113. http://dx.doi.org/10.1016/j.foodchem.2009.03.083.

Lund, M. N., Heinonen, M., Baron, C. P., \& Estévez, M. (2011). Protein oxidation in muscle food: a review. Molecular Nutrition \& Food Research, 55(1), 83-95. http://dx.doi.org/10.1002/mnfr.201000453. PMid:21207515.

Lund, M. N., Hviid, M. S., Claudi-Magnussen, C., \& Skibsted, L. H. (2008). Effects of dietary soybean oil on lipid and protein oxidation in pork patties during chill storage. Meat Science, 79(4), 727-733. http://dx.doi.org/10.1016/j.meatsci.2007.11.008. PMid:22063036.

Mancini, R. A., \& Hunt, M. C. (2005). Current research in meat color. Meat Science, 71(1), 100-121. http://dx.doi.org/10.1016/j. meatsci.2005.03.003. PMid:22064056.

Manessis, G., Kalogianni, A. I., Lazou, T., Moschovas, M., Bossis, I., \& Gelasakis, A. I. (2020). Review: Plant-Derived natural antioxidants in meat and meat products. Antioxidants, 9(12), 1215. http://dx.doi. org/10.3390/antiox9121215. PMid:33276503.

Monahan, F. J., \& Troy, D. J. (1997). Overcoming sensory problems in low fat and low salt products. In A. M. Pearson \& T. R. Dutson (Eds.), Advances in meat research, production and processing of healthy meat, poultry and fish products (Vol. 11, pp. 257-281). London: Blackie Academic and Professional. http://dx.doi.org/10.1007/9781-4613-1125-6_13.

Moore, J., Yousef, M., \& Tsiani, E. (2016). Anticancer effect of rosemary (Rosmarinus officinalis L.) extract and rosemary extract polyphenols. Nutrients, 8(11), 731. http://dx.doi.org/10.3390/nu8110731. PMid:27869665.

Moreno, S., Scheyer, T., Romano, C. S., \& Vojnov, A. A. (2006). Antioxidant and antimicrobial activities of rosemary extract linked to their polyphenol composition. Free Radical Research, 40(2), 223231. http://dx.doi.org/10.1080/10715760500473834. PMid:16390832.

Nieto, G. (2017). Review: biological activities of three essential oils of the lamiaceae family. Medicines, 4(3), 63. http://dx.doi.org/10.3390/ medicines4030063. PMid:28930277.

Nostro, A., Blanco, A. R., Cannatelli, M. A., Enea, V., Flamini, G., Morelli, I., Sudano Roccaro, A., \& Alonzo, V. (2004). Susceptibility of methicillin-resistant staphylococci to oregano essential oil, carvacrol and thymol. FEMS Microbiology Letters, 230(2), 191-195. http://dx.doi.org/10.1016/S0378-1097(03)00890-5. PMid:14757239.

Nostro, A., Roccaro, A. S., Bisignano, G., Marino, A., Cannatelli, M. A., Pizziment, F. C., Cioni, P. L., Procopio, F., \& Blanco, A. R. (2007). Effect of oregano, carvacrol and thymol on Staphylococcus aurus and Staphylococcus epidermidis biofilms. Journal of Medical Microbiology, 56(Pt 4), 519-523. http://dx.doi.org/10.1099/jmm.0.46804-0. PMid:17374894.

Oostindjer, M., Alexander, J., Amdam, G. V., Andersen, G., Bryan, N. S., Chen, D., Corpet, D. E., De Smet, S., Dragsted, L. O., Haug, A., Karlsson, A. H., Kleter, G., de Kok, T. M., Kulseng, B., Milkowski, A. L., Martin, R. J., Pajari, A.-M., Paulsen, J. E., Pickova, J., Rudi, K., Sødring, M., Weed, D. L., \& Egelandsdal, B. (2014). The role of red and processed meat in colorectal cancer development: a perspective. Meat Science, 97(4), 583-596. http://dx.doi.org/10.1016/j. meatsci.2014.02.011. PMid:24769880.

Okamura, N., Fujimoto, Y., Kuwabara, S., \& Yagi, A. (1994). High performance liquid chromatographic determination of carnosic acid and carnosol in Rosmarinus officinalis and Salvia officinalis. Journal of Chromotagraphy A, 679(2), 381-386. http://dx.doi. org/10.1016/0021-9673(94)80582-2.

Oran, S., \& Al-Eisawi, D. (1998). Check-list of medical plants in Jordan. Dirasat. Medical and Biological Sciences, 25(2), 84-112. Retrieved from http://vlibrary.emro.who.int/imemr/check-list-of-medicinalplants-in-jordan

Pereira, D., Pinheiro, R. S., Heldt, L. F. S., Moura, C., Bianchin, M., Almeida, J. F., Reis, A. S., Ribeiro, I. S., Haminiuk, C. W. I., \& Carpes, S. T. (2017). Rosemary as natural antioxidant to prevent oxidation in chicken burgers. Food Science and Technology, 37(Suppl. 1), 17-23. http://dx.doi.org/10.1590/1678-457x.31816.

Race, S. (2009). Antioxidant: the truth about BHA, BHT, TBHQ and other antioxidant used as food additives (pp. 1-46). Tigmor Books. Retrieved from http://www.foodcanmakeyouill.co.uk/ uploads/1/2/7/4/12746572/antioxidants.pdf

Requena, J. R., Levine, R. L., \& Stadtman, E. R. (2003). Recent advances in the analysis of oxidized proteins. Amino Acids, 25(3-4), 221-226. http://dx.doi.org/10.1007/s00726-003-0012-1. PMid:14661085.

Ri, C., Jiang, X., Kim, M., Wang, J., Zhang, H., Wu, S., Bontempo, V., \& Qi, G. (2017). Effects of ditary oregano powder supplementation on the growth performance, antioxidant status and meat quality of broiler chicks. Italian Journal of Animal Science, 16(2), 246-252. http://dx.doi.org/10.1080/1828051X.2016.1274243.

Rowe, C. W., Pohlman, F. W., Brown, A. H. Jr., Baublits, R. T., \& Johnson, Z. B. (2009). Effects of salt, BHA/BHT, and differing phosphate types on quality and sensory characteristics of beef Longissimus Muscles. Journal of Food Science, 74(4), S160-S164. http://dx.doi. org/10.1111/j.1750-3841.2009.01119.x. PMid:19490343.

Sampaio, G. R., Saldanha, T., Soares, R. A., \& Torres, E. A. (2012). Effect of natural antioxidant combinations on lipid oxidation in cooked chicken meat during refrigerated storage. Food Chemistry, 135(3), 1383-1390. http://dx.doi.org/10.1016/j.foodchem.2012.05.103. PMid:22953870.

SAS Institute. (2012). Base SAS 9.3 procedures guide. Cary: SAS Institute.

Sebranek, J. G., Sewalt, V. J. H., Robbins, K. L., \& Houser, T. T. A. (2005). Comparison of a natural rosemary extract and BHA/BHT for relative antioxidant effectiveness in pork sausage. Meat Science, 69(2), 289-296. http://dx.doi.org/10.1016/j.meatsci.2004.07.010. PMid:22062821.

Serpen, A., Gokmen, V., \& Fogliano, V. (2012). Total antioxidant capacities of raw and cooked meats. Meat Science, 90(1), 60-65. http://dx.doi.org/10.1016/j.meatsci.2011.05.027. PMid:21684086.

Shah, M. A., Bosco, S. J. D., \& Mir, S. A. (2014). Plant extracts as natural antioxidants in meat and meat products. Meat Science, 98(1), 21-33. http://dx.doi.org/10.1016/j.meatsci.2014.03.020. PMid:24824531.

Sierżant, K., Korzeniowska, M., Król, B., Orda, J., \& Wojdyło, A. (2018). Oxidative stability of the meat of broilers fed diets supplemented with various levels of blackcurrant extract (Ribes nigrum L.) during different time period. Journal of Chemistry, 2018, 4235091. http:// dx.doi.org/10.1155/2018/3403975.

Smet, K., Rases, K., Huyghebaert, G., Haak, L., Arnouts, S., \& Smet, S. (2008). Lipid and protein oxidation of broiler meat as influenced by dietary natural antioxidant supplementation. Poultry Science, 87(8), 1682-1688. http://dx.doi.org/10.3382/ps.2007-00384. PMid:18648067.

Sonam, K. S., \& Guleria, S. S. (2017). Review article: synergistic antioxidant activity of natural products. Annals of Pharmacology and Pharmacutics, 2(8), 1086.

Sun, W. Q., Zhang, Y. J., Zhou, G. H., Xu, X. L., \& Peng, Z. Q. (2010). Effect of apple polyphenol on oxidative stability of sliced cooked cured beef and pork hams during chilled storage. Journal of Muscle Foods, 21(4), 722-737. http://dx.doi.org/10.1111/j.1745-4573.2010.00215.x. 
Taghvaei, M., \& Jafari, S. M. (2015). Application and stability of natural antioxidants in edible oils in order to substitute synthetic additives. Journal of Food Science and Technology, 52(3), 1272-1282. http:// dx.doi.org/10.1007/s13197-013-1080-1. PMid:25745196.

Thongtan, K., Toma, R. B., Reiboldt, W., \& Daoud, A. (2005). Effect of rosemary extract on lipid oxidation and sensory evaluation of frozen, precooked beef patties. Journal of Foodservice, 16(3-4), 93104. http://dx.doi.org/10.1111/j.1745-4506.2005.00013.x.

Ultee, A., Bennik, M., \& Moezelaar, H. J. (2002). The phenolic hydroxyl group of carvacrol is essential for action against the food-borne pathogen Bacillus cereus. Applied and Environmental Microbiology, 68(4), 1561-1568. http://dx.doi.org/10.1128/AEM.68.4.15611568.2002. PMid:11916669.

Velasco, V., \& Williams, P. (2011). Improving meat quality through natural antioxidants. Chilean Journal of Agricultural Research, 71(2), 313-322. http://dx.doi.org/10.4067/S0718-58392011000200017.

Xiao, S., Zhang, W. G., Lee, E. J., Ma, C. W., \& Ahn, D. U. (2011). Effect of diet, packaging, and irradiation on protein oxidation, lipid oxidation, and color of raw broiler thigh meat during refrigerated storage. Poultry Science, 90(6), 1348-1357. http://dx.doi.org/10.3382/ ps.2010-01244. PMid:21597078.

Yanishlieva, N. V., Marinova, E. M., Gordon, M. H., \& Raneva, V. G. (1999). Antioxidant activity and mechanism of action of thymol and caracrol in two lipid systems. Food Chemistry, 64(1), 59-66. http://dx.doi.org/10.1016/S0308-8146(98)00086-7.

Zahid, A., Seo, J. K., Park, J. Y., Jeong, J. Y., Jin, S. K., Park, T. S., \& Yang, H. S. (2018). The effects of natural antioxidants on protein oxidation, lipid oxidation, color, and sensory attributes of beef patties during cold storage at $4{ }^{\circ} \mathrm{C}$. Korean Journal for Food Science of Animal Resources, 38(5), 1029-1042. http://dx.doi.org/10.5851/ kosfa.2018.e36. PMid:30479509.

Zhai, H., Liu, H., Wang, S., Wu, J., \& Kluenter, A.-M. (2018). Potential of essential oils for poultry and pigs. Animal Nutrition, 4(2), 179-186. http://dx.doi.org/10.1016/j.aninu.2018.01.005. PMid:30140757. 